\section{文}

\section{献}

1) F.I. LaQue in Corrosion Handbook, edited by $\mathrm{H}$. H. Uhlig, John Wiley \& Sons, Inc. N. Y. (1948)

2) H. H. Uhlig: Corrosion and Corrosion Control, p. 153, John Wiley \& Sons, N. Y. (1963)

3) F.N. Speller: Corrosion, Causes and Prevention, p. 82, McGraw-Hill, N. Y. (1951)

4) A. de La Rive: Annales de Chimie et Physique, 43, 425 (1830)

5) M. Stern: J. Electrochem. Soc., 102, 663 (1955)

6) Z. Foroulis: D.Sc. Thesis, Department of Metallurgy, Mass. Inst. of Tech. (1961)

7) E. Heyn \& O. Bauer: J. Iron Steel Inst., 79, 109 (1909)

8) H. H. Uhlig in Relation of Properties of Microstructure, Transactions of Am. Soc. Metals, pp. 189 $\sim 208$, Cleveland, Ohio (1954)

9) H. H. Uhlig: Trans. Am. Soc. Metals., 30, 947 (1942)

10) A. Lena: Metal Progress, 66, 97 99 (1954)

11) G. Krönke \& G. Masing: Werkstoffe und Korrosion, 4, 86 (1953)

12) W. Tragert \& W. Robertson: J. Electrochem. Soc., 102, 86 (1955)

13) R. Bakish \& W. Robertson: ibid., 103, 320 (1956)

14) A. Gwathmey: Annals New York Academy of Sciences, Series II, 53, No. 4, p. 992 (1951)

15) H. Gatos: Science, 137, 311 (1962); H. Gatos \& M. Lavine: J. Electrochem. Soc., 107, 427 (1960)

16) H. Copson in Corrosion Handbook, edited by H. H.
Uhlig, p. 276, John Wiley and Sons, Jnc., N. Y. (1948)

17) T. Hoar \& J. West: Proc. Royal Soc., 268, 304 (1962)

18) H. H. Uhlig, R. White \& J. Lincoln, Jr.: Acta Metallurgica, 5, 473 (1957)

19) H. H. Uhlig \& R. White: Trans. Am. Soc. Metals, 52, 830 (1960)

20) H. H. Uhlig \& J. Sava: Paper presented at Second Int'l Congress on Metallic Corrosion, N. Y. (1963)

21) W. Robertson \& H. H. Uhlig; J. Appl. Phys., 19, 814 (1948)

22) N. Tomashov: Corrosion, 14, $229 \mathrm{t} \sim 236 \mathrm{t}$ (1958) May

23) M. Stern \& H. Wissenberg: J. Electrochem. Soc., 106, 759 (1959)

24) E. Fellen: J. Electrochem. Soc., 108, 490 (1961)

25) J. Bénard \& J. Talbot: Compt. Rend., 225, 411 (1947)

26) M. Bénard \& O. Coquelle: Rev. de Metallurgie, 44, 82 (1947)

27) H. H. Uhlig \& A. Brasunas: J. Electrochem. Soc., 97, 448 (1950)

28) F. Young, J. Cathcart \& A. Gwarthmey: Acta Metallurgica, 4, 145 (1956)

29) A. Gwarthmey \& K. Lawless in The Surface Chemistry of Metals and Semi-Conductors, edited by H. Gatos, p. 483, John Wiley and Sons, Inc. (1960)

30) H. H. Uhlig, J. Pickett \& J. MacNairn: Acta Metallurgica, 7, 111 (1959)

31) H. H. Uhlig: Acta Metallurgica, 4, 541 (1956)

\title{
塩化物環境における 304 ステンレス鋼の応力腐食割れ*
}

\author{
K. C. Thomas**, H. M. Ferrari** \& R. J. Allio**
}

\section{緒}

\section{言}

從来の経験によれば，オーステナイト・ステンレス鋼 の応力腐食事故は, 比較的低温の濃厚塩化物溶液および 高温のきわめて希薄な塭化物溶液で発生している1,2)。ま た応力腐食による破断時間温度の上昇によって著しく 短縮されることが見出されている3゙。放射線分解の結果 として原子炉に存在する酸素4) および放射線損傷5) は応 力腐食の傾向を強めるという報告もある。他方, 低温の 高濃度塩化物溶液中での結果によると, 酸素は応力腐食 による破断時間にほとえど影響を与えないといわれてい る6)。そのほふ, 塩化マグネシウム溶液の $\mathrm{pH}$ 注オース テナイト・ステンレス鋼の忘力腐食に影響を及ぼし，酸 性の増加は割れを促進する3,6,7) と報告されている。

過熱水蒸気中における 304 ステンレス鋼の事故を調査 した結果，割れが発生している部分に著しい塭化物の濃 縮が示され2)，この部分は蒸気から湿分が除去される範 囲と一致していた。これらの塩化物は検出できる程度の 銅や鉄の重金属を含有することが見出されている。

* 訳者：栂野秀夫（東京工業試験所第 6 部）

* Westinghouse Electric Corp., Atomic Power Division (原文) Stress Corrosion of Type 304 Stainless Steel In Chloride Environments, Corrosion, Vol. 20, No. 3 , 89 t $92 \mathrm{t}$ (1964) Mar.
Francis ${ }^{8)}$ は有機物の環境を含む多くの媒質中で 304 ス テンレス鋼の応力腐食割れを観察した。また，沸騰カ七 イアルカリ溶液中でも応力腐食割れが報告されてい る1,9)。Berg と Henrickson ${ }^{10)}$ は $\mathrm{pH}$ 一定の塩化物溶 液による実験で，破断時間は陽イオンとは無関係で塩素 イオン濃度に依存することを見出し，15\% 以下の塩素 イオン濃度では割れを生じないと報告した。しかし，こ れらの実験結果にもかかわらず，陽イオン陰イオンの両 者とも応力腐食に関倸のあることが予想される。このタ イプの事故は必ずしも塩化物溶液にのみ限定されること はないのである。

Coleman $5^{11)}$ は, 応力腐食現象 における原子あるいはイオンの吸着による割れ生成の表 面エネルギーの低下に基づくと提案した。塩化マグネシ ウム溶液中でのオーステナイト鋼の場合, 割れを発生さ せる表面エネルギーは一桁低下すると報告されている。 これらの研究者は, また $\mathrm{Mg}^{2+}, \mathrm{Cl}^{-}, \mathrm{H}^{+}, \mathrm{OH}^{-}$のぞれ かが応力腐食割れに密接な関係があると述べているが， どのイオンが該当するかを明確にしなかった。

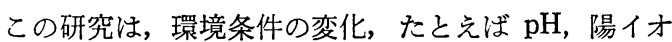
ンの種類, 塩化物濃度, 温度の中, 304 ステンレス鋼の 応力腐食割れに強く影響する因子の決定を目的とした。 
始めの試験は低温高濃度の塩化物溶液中で行なわれた が, 後の試験は, 原子炉の運転環境に近い条件，すなわち 高温低濃度の塩化物溶液で行なうべく計画されている。

\section{実 験 方 法}

実験に法次の化学組成, 機械的性質, 結晶粒度を持つ 304 ステンンス鋼を使用した。

重 量 \%: C $0.06, \mathrm{Ni} 9.68, \mathrm{Cr} 19.02$, Mn 1.23, Mo 0.30, Fe 残

$0.2 \%$ 降伏強さ： $41,600 \mathrm{psi}$

抗 張 力: $93,750 \mathrm{psi}$

伸 び (2 in): $60 \%$

結 晶 粒 度: ASTM No. 7 8

試料は直径 0.035 in の線材で, 焼鈍状態で受け入れ たものをアセトンおよび無水のエチルアルコールで洗浄 して試験に供した。試験容器は図 1 亿示すような還流冷 却器付きの応力腐食せルで, 容量は $150 \mathrm{~m} l$ である。塭 化物の熱溶液はセルのサイドアームから注入されるが, その前にセルを数分間予熱しておく。この液は冷えた毛 細管の部分で㠜固し，シールの役を果す。負荷はプーリ ーシステムを使って試験片(線)に直接与えた。

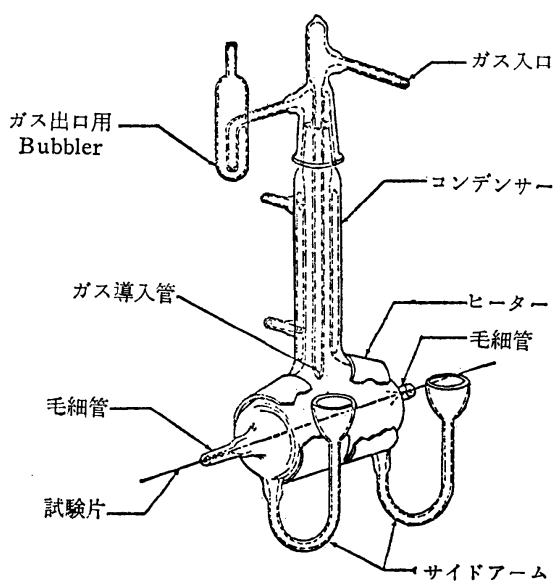

図 1 応力腐食セル

試験液には塩化マグネシウム, 塩化リチウム, 塭化カ ルシウムの沸騰溶液および沸点以下の塩化マグネシウム 溶液を用いた。後者の場合は鉄-コンスタンタンサーモ カップルを用いる温度調節器により $\pm 1 / 2{ }^{\circ} \mathrm{C}$ の確度で 温度を調節した。種々の溶液の $\mathrm{pH}$ 值は $80^{\circ} \mathrm{C}$ て測定 し, また必要な場合はこの温度で $\mathrm{HCl}$ を加えて $\mathrm{pH}$ を 調節した。セルの溶液上はすべて空気雾囲気で実験を行 なったので, 任意の溶液に対しほぼ一定の酸素濃度を設 定したことになる。なおこの研究では応力腐食に対する 酸素の影響を検討しなかった。

\section{実験結果と考察}

陽イオンの種類による影響

この実験は $\mathrm{MgCl}_{2}, \mathrm{CaCl}_{2}, \mathrm{LiCl}$ の $125^{\circ} \mathrm{C}$ 沸騰溶液
で行なわれた。塩が完全に解離してイオンになると仮定 して, この 3 種の溶液の塩素イオン濃度はほぼ等しく $27 \%$ とした。3 種の溶液に対する応力と破断時間の関 係は, $80^{\circ} \mathrm{C}$ で測った液の $\mathrm{pH}$ 值を付記して図 2 に示し てある。ところで，重要因子である $\mathrm{pH}$ 值は $\mathrm{LiCl}, \mathrm{Ca}$. $\mathrm{Cl}_{2}, \mathrm{MgCl}_{2}$ の順で低くなっているが，破断時間もこの 順で短かくなっている。

$\mathrm{pH}$ 因子の変動を除くため, $80^{\circ} \mathrm{C}$ で $\mathrm{pH} 2.8$ ，すなわ ち塩素イオン濃度約 $27 \%$ の $\mathrm{MgCl}_{2}$ 試薬の $80^{\circ} \mathrm{C}$ にお ける $\mathrm{pH}$ 值と同じ $\mathrm{pH}$ 值に調節した $\mathrm{CaCl}_{2}$ と $\mathrm{LiCl}$ の 溶液で試験を行なった。

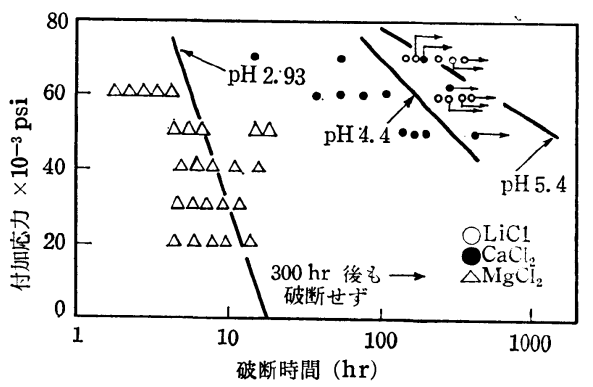

図 $2125^{\circ} \mathrm{C}$ 沸騰条件下の 304 ステンレス鋼の破断 応力に対する塩化物溶液の影響 塩素イオン濃度は約 $27 \%, \mathrm{pH}$ は $80^{\circ} \mathrm{C}$ における測定値

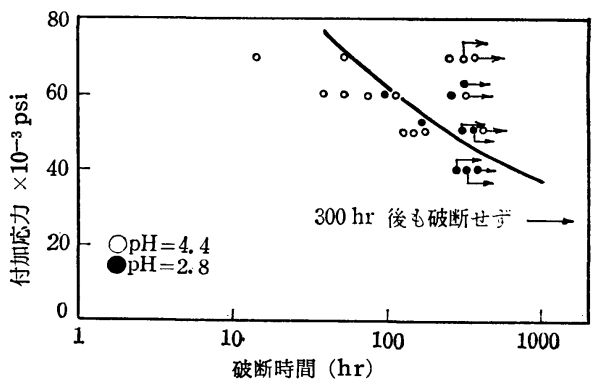

図 $3126^{\circ} \mathrm{C}$ の沸騰 $\mathrm{CaCl}_{2}$ 溶液中における 304 ス テンレス鋼の応力腐食割れに対する液の $\mathrm{pH}$ の影響

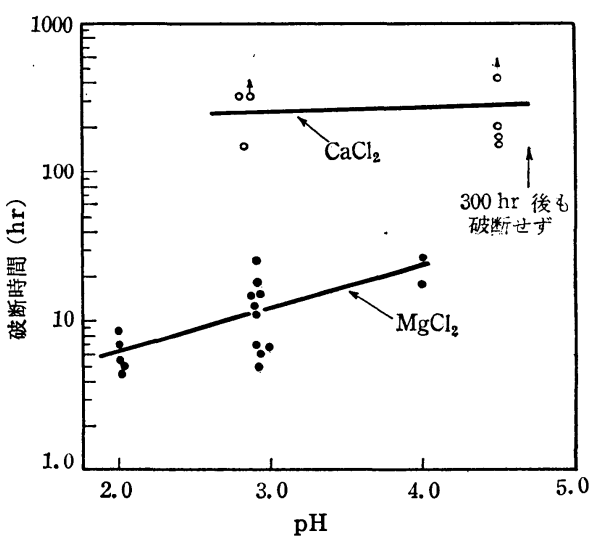

図 $4125^{\circ} \mathrm{C}$ の $\mathrm{MgCl}_{2}$ および $\mathrm{CaCl}_{2}$ 沸騰溶液中に おける付加応力 $50,000 \mathrm{psi}$ の 304 ステンレス鋼 の破断時間に対する $\mathrm{pH}$ の影響 
2 種の $\mathrm{pH}$ レベルにおける $\mathrm{CaCl}_{2}$ 溶液中での結果は 図 3 亿示されるが， $\mathrm{pH}$ の効果は明らかでない。 $\mathrm{pH} 2.8$, 5.4 の $\mathrm{LiCl}$ 溶液で行なった同種の実験でも破断時間に ほとえど差は認められなかった。この実験結果は, 種々 の溶液間の破断時間の差は液の $\mathrm{pH}$ によよりむしろ陽 イオンの種類によって生ずることを示している。これら の結果は破断時間は陽イオンの種類と無関係と主張する Berg と Henrikson ${ }^{10)}$ の主張と相反する。しかし Berg と Henrikson の結果は限られたデータに基づいており， 一方図 4 亿示市種々の $\mathrm{pH}$ 值における $\mathrm{MgCl}_{2}$ と $\mathrm{CaCl}_{2}$ 溶液に対するこの報告の結果は，明らかに陽イオンの種 類の重要性を実証している。すなわち，どの $\mathrm{pH}$ 值にお いても $\mathrm{CaCl}_{2}$ 溶液中での破断時間は $\mathrm{MgCl}_{2}$ 溶液中での それに比べて著しく長い。この破断時間における差異 は，ただ陽イオンの種類の差にのみ基づいている。結局 この実験結果によると, 破断時間は $\mathrm{Mg}^{2+}, \mathrm{Ca}^{2+}, \mathrm{Li}^{+}$ の順で増加している。

応力腐食現像に対する陽イオンの種類の影響は，イオ ンの吸着が重要な役割を演ずる表面効果によって説明で きるかもしれぬ。Coleman ら ${ }^{11)}$ は $\mathrm{MgCl}_{2}$ 溶液中での割 机発生に要する表面エネルギーの減少に対する原因とし てある種の陽イオン吸着の可能性を提案した。陽イオン の金属表面への吸着に影響する二つの因子は原子価とイ オンの大きさである。イオン半径は，一価のイオン $\left(\mathrm{Li}^{+}, \mathrm{Na}^{+}\right)$に対して $\mathrm{Li}, \mathrm{Na}$ の順で, 二価のイオン $\left(\mathrm{Mg}^{2+}, \mathrm{Ca}^{2+}\right)$ に対して $\mathrm{Mg}$, $\mathrm{Ca}$ の順で大きくなる。そ れゆ各グループの中で，割れ敏感性は陽イオンの大き さの増大とともに減ずることになる。しかし錯イオンの 存在はもちろん応力腐食の動力学を変えることができ る。

\section{pH の影響}

$\mathrm{pH}$ の影響は $125^{\circ} \mathrm{C}$ で沸騰する $\mathrm{MgCl}_{2}, \mathrm{CaCl}_{2}$ 溶液 中で詳細に研究された。適当な電極がないので $80^{\circ} \mathrm{C}$ 以 上の温度で $\mathrm{pH}$ を正確に測定することは困難である。し

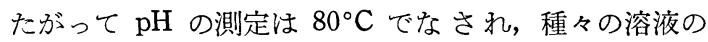
$\mathrm{pH}$ 值法この温度で比較された。 $80^{\circ} \mathrm{C} て ゙$, 希望する $\mathrm{pH}$ 值にするため, $\mathrm{HCl}$ あるいは $\mathrm{Mg}(\mathrm{OH})_{2}$ の添加が行なる れたが，この添加による塩素イオン濃度の変化は $0.1 \%$ 以下であった。 $125^{\circ} \mathrm{C}$ の $\mathrm{CaCl}_{2}, \mathrm{MgCl}_{2}$ 溶液中で 50,000 psi 応力下における破断時間は図 4 亿示されている。 $\mathrm{MgCl}_{2}$ の場合，破断時間は $\mathrm{pH}$ 值の増加とともに增大 しており，これは Barnartt と Van Rooyen6) の結果 と一致している。 $\mathrm{CaCl}_{2}$ 溶液の場合, $\mathrm{pH} 2.8 \sim 4.4$ の 範囲に打いて $\mathrm{pH}$ 沙破断時間にほとえど影響を与えな い。Anderson?）の報告によると $\mathrm{pH}$ の増加は破断時間 を増しているように思えるが，この例における破断時間 の $\mathrm{pH}$ 依存性洼著しくなく, しかももっと大きな $\mathrm{pH}$
範囲から得られている。

Barnartt と Van Rooyen ${ }^{6)}$ は $\mathrm{MgCl}_{2}$ 溶液の $\mathrm{pH}$ を $\mathrm{HCl}$ 添加によって下げた場合の割れの増加を, 水素発生 および金属溶解速度の増大により割れ密度が増したため と説明した。また十分に $\mathrm{HCl}$ を添加すると割れ開始期 間 (initiation period) は完全に消失する。任意のカソー ド復極剈（たとえば $\mathrm{Fe}^{3+}$ ) も，これがアノード反応定防 害しないかぎり同様な影響をもたらすことが予想されよ う。支配的なアノード反応は $\mathrm{Ni}$ リッチな表面の溶解で あり, カソード反応は主として水素発生であると説明さ れた。 $\mathrm{CaCl}_{2}$ の場合破断時間は著しく長いので，高い $\mathrm{pH}$ 值における破断時間の增加はもっと破断時間の短か い場合に比べて検出が困難である。したがって Barnartt および Van Rooyen によって提案された機構は $\mathrm{CaCl}_{2}$ 溶液の場合においても適用できるかもしれない。

\section{温度の影響}

304 ステンレス鋼の破断時間に対する温度の影響は, $50,000 \mathrm{psi}$ の応力レベルで, 塩素イオン濃度を 3 種に変 えた $\mathrm{MgCl}_{2}$ 溶液により検討した。試験温度は沸点以下 で，したがって温度調節器で定温を維持した。検討した 温度範囲および溶液の特性注 1 亿示される。17.5\% $\mathrm{Cl}^{-}$濃度の液に対してのみ $\mathrm{pH} 4.0$ と 2.8 で試験が行 なわれたが，破断時間にはほとえど差が認められなかっ た。3 種の塩素イオン濃度溶液の $\mathrm{pH}$ 值はほぼ等しい ので, 破断時間の変動は温度と塩素イオン濃度の両因子 に基づくことになる。

表 $1 \mathrm{MgCl}_{2}$ 溶液の沸騰温度と $\mathrm{pH}$

\begin{tabular}{|c|c|c|c|}
\hline $\begin{array}{c}\text { 塩素イオン } \\
(\%)\end{array}$ & $\begin{array}{c}\text { 試験温度範团 } \\
\left({ }^{\circ} \mathrm{C}\right)\end{array}$ & 沸 $\left({ }^{\circ} \mathrm{C}\right)^{\text {点 }}$ & $\begin{array}{c}80^{\circ} \mathrm{C} \text { で測定した } \\
\mathrm{pH}\end{array}$ \\
\hline $\begin{array}{l}17.5 \\
27 \\
31\end{array}$ & $\begin{array}{r}80 \sim 110 \\
100 \sim 125 \\
120 \sim 142\end{array}$ & $\begin{array}{l}110 \\
125 \\
142\end{array}$ & $\begin{array}{l}4.0,2.8 \\
2.8 \\
2.63^{*}\end{array}$ \\
\hline
\end{tabular}

外挿值

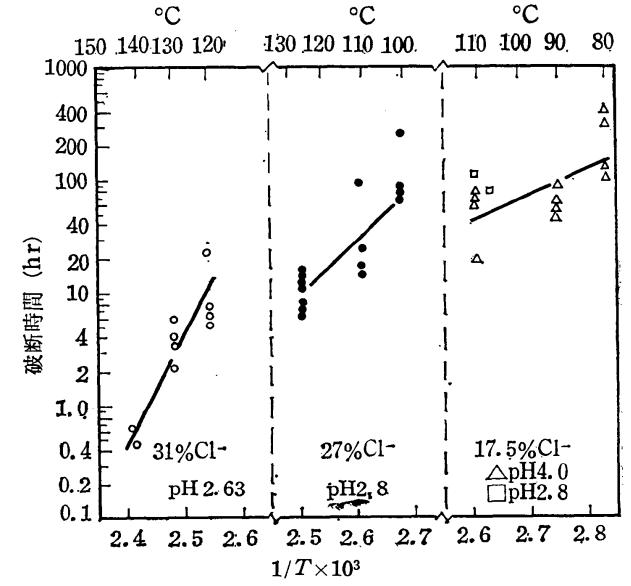

図 5 種々の塩素イオン濃度の $\mathrm{MgCl}_{2}$ 溶液中にお ける付加応力 $50,000 \mathrm{psi}$ の 304 ステンレス鋼の 破断時間に対する温度の影響 
実験の結果は図 5 に示される。Hoar と Hines ${ }^{3)}$ は沸 騰 $\mathrm{MgCl}_{2}$ 溶液中における 304 ステンレス鋼の破断時間 の温度依存性に関し次の式を提案している。

$$
t_{f}=A \exp (B / T)
$$

$t_{f}$ : 破断時間, $T:$ 絶対温度, $A, B:$ 常数

この種の関係がわれわれのデータにもあると仮定する そ, それぞれの塩素イオン濃度に対応して 3 本の直線が 得られる。31\% Cl-に対する傾斜は，ほぼ同じ塩素イオ ン濃度の $\mathrm{MgCl}_{2}$ 溶液（約 $42 \% \mathrm{MgCl}_{2}$ 溶液）について Hines ${ }^{3)}$ が得たものと同一である。

Hines は破断時間が塩化物濃度の減少とともに増大す るが, この増加は, 濃度の減少に伴う沸点の低下から子 想されるものより大きいと報告している。われわれの研 究結果は上述の報告と一致しない。図 5 に示すように, $125^{\circ} \mathrm{C}$ における $31 \% \mathrm{Cl}^{-}$溶液と $27 \% \mathrm{Cl}^{-}$溶液中での 破断時間はそれぞれ 7 時間と 11 時間であり，この差は 実験誤差の範囲内にある。また， $110^{\circ} \mathrm{C}$ における $27 \%$ $\mathrm{Cl}^{-}$溶液と $17.5 \% \mathrm{Cl}^{-}$溶液中での破断時間はとれぞれ 35 時間と 45 時間である。この值もやはり実験誤差の範 囲内にある。このように温度は塩素イオン濃度よりはる かに大きな影響を持つことは明らかである。この結論は 塩化物濃度の著しく薄い $(900 \mathrm{ppm} \mathrm{NaCl})$ 高温溶液中で 割れが発生しうる事実 ${ }^{13}$ によって容易に実証されてい る。これとは逆に, 塭化物高濃度（飽和 $\mathrm{NaCl}$ 溶液）の 低温 $\left(100^{\circ} \mathrm{C}\right)$ 溶液中で同種材料に割れを発生させるこ とは困難である8)。

一定の圧力, 一定の塭素イオン濃度の条件下では, そ の溶液のその圧力における沸点以上に温度を上げること はできない。したがって，この実験装置で破断時間に対 する高い温度（常圧沸点）の影響を検討するとと法不可 能である。304 ステンレス鋼の応力腐食割れ特性に対す るより高い温度の影響を調べるため, オートクレーブを 用いる実験を現在行なっている。

\section{結論}

1) 一定の応力, 温度, $\mathrm{pH}$ 值, 塩素イオン濃度にお ける種々の塩化物溶液中での 304 ステンレス鋼の破断時 間の差異は, 液中に存在する陽イオンの種類に依存する。 破断時間は $\mathrm{Mg}^{2+}, \mathrm{Ca}^{2+}, \mathrm{Li}^{+}$の順に増加する。これは たぶえ陽イオンの大きさと原子価の作用による吸着効果 に基づく提案した。

2) $\mathrm{MgCl}_{2}$ 溶液中の一定応力下における 304 ステン レス鋼の破断時間は $\mathrm{pH}$ の上昇とともに増大する。 $\mathrm{Ca}$.
$\mathrm{Cl}_{2}$ 溶液中では $\mathrm{pH}$ 注破断時間にほとんど影響がないよ うに見える。乙かし $\mathrm{CaCl}_{2}$ 溶液中における著しく長い 破断時間は, 破断時間变動の判定を困難にしている。

3) $\mathrm{MgCl}_{2}$ 溶液中での一定応力下の 304 ステンレス 鋼の破断時間に対し, 温度は塩素イオン濃度より著しく 大きな影響を持っている。

\section{謝辞}

著者は，この実験で用いた応力腐食セルを供与された Westinghouse Research のS. Barnartt 博士に感謝す る。

\section{参考文 献}

1) P.P. Snowden: Stress-Corrosion of Austenitic Stainless Steels by High-Temperature Solutions, J. Iron \& Steel Institute, 194, Pt. 2, 181 189 (1960) Feb.

2) C. N. Spalaris, R.F. Boyle, T. F. Evans \& E. L. Esch: Design Fabrication and Irradiation of Superheat Fuel Element SH-4 B in VBWR. USAEC Report GEAP-3796, General Electric Company, Atomic Power Equipment Dept. (1961) Sept.

3) T. P. Hoar \& J. G. Hines: The Stress-Corrosion Cracking of Austenitic Stainless Steels, Pt. 1, J. Iron \& Steel Institute, 182, Pt. 2, 124 143 (1956) Feb.

4) W. L. Williams \& J. F. Eckel: Stress-Corrosion of Austenitic Stainless Steels in High Temperature Waters: American Society of Naval Engineers Journal, 68, 93 (1956)

5) G. G. Gaul \& W. L. Pearl: Corrosion of Type 304 Stainless Steel in Simulated Superheat Reactor Environments. USAEC Report GEAP-3779, General Electric Company, Atomic Power Equipment Dept. (1960) Oct.

6) S. Barnartt \& D. Van Rooyen: Anodic Behavior of Austenitic Stainless Steels and Susceptibility to Stress Corrosion Cracking, J. Electrochem. Soc., 108, No. 3, 222 229 (1961) Mar.

7) B. Anderson: Study of Stainless Steel Stress Corrosion Cracking by Potential Measurements, Corrosion, 18, No. 12, $425 \mathrm{t} \sim 432 \mathrm{t}$ (1962) Dec.

8) H.T. Francis: The Mechanism of Stress Corrosion in Stainless Steels. Armour Research Foundation Final Report ARF 2181-12 (1959 60)

9) E.G. Brush: Behavior of Type 347 Stainless Steel in Sodium Hydroxide at Elevated Temperatures. KAPL-M-EGB-22 (1956)

10) S. Berg \& S. Henrikson: Stress Corrosion Cracking of Austenitic Stainless Steels in Varying Concentrations of Alkali and Earth Alkali Chlorides, Jenkoat Ann., 144, 392 396 (1960)

11) E. G. Coleman, D. Weinstein \& W. Rostoker: On a Surface Energy Mechanism for Stress Corrosion Cracking, Acta Met., 9, No. 5, 491 496 (1964) May

12) J. G. Hines: Physical Metallurgy of Stress Corrosion Fracture, 240, Interscience, New York and London (1959)

13) W.W. Kirk, F.H. Beck \& M. G. Fontana: Physical Metallurgy of Stress Corrosion Fracture, 227 Interscience, New York \& London (1959) 